\title{
Nosema notabilis (Microsporidia), its ultrastructure and effect on the myxosporean host Ortholinea polymorpha
}

\author{
Iva Dyková*, Jiří Lom \\ Institute of Parasitology, Academy of Sciences of the Czech Republic, Branišovská 31, CZ-370 05 České Budějovice, \\ Czech Republic
}

\begin{abstract}
Nosema notabilis Kudo, 1939 produces chain-forming meronts with a dense cell coat in direct contact with the host cell cytoplasm. Cytoplasmic microtubules and membranaceous whorls could be observed in meront cytoplasm. Sporonts differ in that they have a thicker cell wall and more conspicuous endoplasmic reticulum (ER) cisternae. Sporoblasts have an externally ridged cell wall. Spores have an apically located anchoring disc, an isofilar polar tube with 6 to 9 turns and polyribosomal strands in the sporoplasm. Diplokarya occur in all stages. Heavily infected plasmodia of Ortholinea polymorpha (Davis, 1917) reveal marked pathological signs. The most prominent are reduction of surface projections and/or pinocytosis, inflated mitochondria with altered inner structures, affected vegetative nuclei, damage to generative cells and occurrence of various anomalous formations in the plasmodium cytoplasm. The damage may result in complete desintegration of the plasmodium. However, the development of the microsporidian is affected by a remarkably high percentage of teratological stages revealing membranaceous and tubular structures
\end{abstract}

KEY WORDS: Nosema notabilis $\cdot$ Ultrastructure $\cdot$ Hyperparasitism - Ortholinea polymorpha

\section{INTRODUCTION}

Several microsporidian species have been recorded as hyperparasites of parasitic organisms of fishes since the finding of Nosema marionis (Thélohan, 1895) in Leptotheca coris (Géorgevitch, 1916), a parasite in the gall bladder of Coris julis (Thélohan 1895): Nosema notabilis Kudo, 1939 from Ortholinea polymorpha (Davis, 1917) Shulman, 1962 in the urinary bladder of Opsanus tau and $O$. beta (Kudo 1939); $N$. ceratomyxae Diamant \& Paperna, 1985 from Ceratomyxa sp. in Siganus argenteus, $S$. luridus and $S$. rivulatus (Diamant \& Paperna 1985); and Microsporidium acanthocephali Loubes, Maurand \& de Buron, 1988 and $M$. propingui Loubes, Maurand \& de Buron, 1988 both, from 3 species of acanthocephalans infecting 4 species of coastal marine fishes (Loubes et al. 1988).

The developmental cycle of Nosema notabilis as observed by light microscopy was described by Kudo

•E-mail: iva@paru.cas.cz
(1939, 1944). According to him, amoeboid binucleate meronts divide to produce 2 uninucleate meronts which grow, become binucleate and divide into uninucleate forms again. Eventually, meronts develop into diplokaryotic spindle-form meronts which divide while staying diplokaryotic. Then they transform into diplokaryotic sporonts which keep dividing and the product of this division becomes a diplokaryotic sporont which transforms directly into a sporoblast, and this in turn develops into a binucleate spore.

Kudo also gave a detailed account (1944) of the development of the myxosporean host, Ortholinea polymorpha, describing formation of pansporoblasts by the union of 2 generative cells. He noticed degenerated or hypertrophic nuclei in heavily infected host trophozoites, a complete inhibition of sporogony and reduced pseudopodia formation. In 1972, Lom \& Weiser presented a brief SEM observation of the finely wrinkled surface of Nosema notabilis spores.

In the present paper, we record ultrastructural observations on the development of the parasite and changes it produces in the host plasmodium. 


\section{MATERIALS AND METHODS}

The hosts, toadfish Opsanus tau, were collected in the vicinity of Chesapeake Biological Laboratory, Solomons Island, Maryland (USA) in November 1969. Samples from infected fishes were prepared in 2 ways for further processing: either small pieces of the urinary bladder wall with attached plasmodia of Ortholinea polymorpha were fixed, or the mass of plasmodia floating within the bladder contents was expelled into the fixative. The samples were fixed in cold $2 \%$ glutaraldehyde in $0.1 \mathrm{M}$ phosphate buffer for 2 to $4 \mathrm{~h}$, rinsed in phosphate buffer and postfixed in $1 \%$ osmic tetroxide in veronal acetate buffer. The released plasmodia were processed as pellets in agar. Ultrathin sections were double stained with uranyl acetate and lead citrate and observed in Hitachi II B and JEOL JEM 1010 electron microscopes at 75 and $60 \mathrm{kV}$, respectively.

\section{RESULTS}

\section{Host plasmodium}

Ortholinea polymorpha forms in the urinary bladder of Opsanus tau amoeboid plasmodia which are up to $100 \mu \mathrm{m}$ in size, most of them averaging 40 to $60 \mu \mathrm{m}$, and have finger-like pseudopodia. While a great many plasmodia are attached by means of tight junctions to the bladder epithelial cells, the rest float freely in the bladder lumen. Plasmodia are mostly polysporous, producing subspherical spores with an average breadth and width of $8.5 \mu \mathrm{m}$, the thickness averaging $6 \mu \mathrm{m}$. A detailed description of the myxosporean is found in Kudo (1944).

At the ultrastructural level, uninfected plasmodia contained vegetative nuclei and generative cells, most of which were engaged in various stages of sporogenesis, including pansporoblast formation and following the pattern well known from other myxosporeans. In addition, cell organelles like mitochondria, endoplasmic reticulum (ER) cisternae, Golgi bodies, and free ribosomes existed as well as a variety of vesicles and small vacuoles. The surface revealed thin projections and pinocytosis.

Heavily infected plasmodia (Figs. 1 \& 2) displayed a plethora of developmental stages of the microsporidian. In many of them, a complete series from meronts to mature spores was represented. Infected plasmodia revealed many changes evidently induced by the hyperparasite. Some plasmodia were completely devoid of finger-like surface projections, usually about $0.6 \mu \mathrm{m}$ long, but still retained surface invaginations, indicating pinocytotic activity (Fig. 1) while in others surface projections persisted but not the pinocytotic vesicles
(Fig. 2). Vegetative nuclei showed signs of pyknosis; sometimes several nuclei were grouped together. Generative cells (Fig. 3) contained unusual vacuoles either seemingly empty or full of fine globules, some of the cells being reduced to cell membranes containing amorphous material. There was a number of electron lucent vacuoles, small and large, and of moderately dense vesicles of different sizes. Mitochondria in uninfected plasmodia (Fig. 4) had a rather lucent matrix; 1 large crista extending through its volume and a few tubular cristae or tiny cristae attached to the inner membrane of the mitochondrium. In infected plasmodia, many if not all mitochondria were largely inflated (Figs. 1, 5 \& 6) with rather densely granular matrix in which the cristae were difficult to distinguish, and often with a large dense inclusion. Degenerative processes in the cytoplasm were reflected by irregular dense structures. Extensive areas of the plasmodium were filled by finely granular structure (Fig. 8) impossible to identify as ribosomes or glycogen granules. Sometimes, meshworks of convoluted ER profiles could be discerned in the cytoplasm (Fig. 7). Sporogenesis was obviously inhibited and affected plasmodia revealed a minimum number of mature spores.

Heavily infected plasmodia eventually disintegrated and the released cell debris, and parasite stages contaminated the pellets prepared for EM examination.

\section{Nosema notabilis developmental stages}

Cells considered to be early meronts (Fig. 9) had a diplokaryon occupying most of the cell volume, the 2 nuclei adhering to each other along a large flat surface. There were a few cisternae of rough endoplasmic reticulum (RER), some free ribosomes and occasionally a small structure of membranous whorls (Fig. 9, arrow). These whorls were sometimes also situated within the nuclear envelope. The cell membrane was covered with a thin dense cell coat and was in direct contact with the host's cytoplasm.

Part of the chain of meronts can be seen in Fig. 11; the left end is continuous with the part with other diplokarya. In these meronts, RER cisternae also occurred as small swollen vesicles. In the cytoplasm, free microtubules extended (Figs. 10 [arrow] \& 11).

Sporonts were characterised by a thicker (45 $\mathrm{nm}$ ) dense cell wall (Fig. 12) and by more conspicuous RER cisternae. Gradually, vesicles with dense contents appeared, constituting part of the nascent Golgi system (Fig. 13). In the ellipsoidal sporoblasts (Fig, 14), the polar tube had its origin in the primordial polar cap (Fig. 16) and the first turns of the tube, at first isolated, appeared beneath the sporoblast wall (Fig. 14). Dense Golgi vesicles persisted for some time in the posterior 
end of the spore close to the coil of the tube (Figs. 14, 18). Under higher magnification, the sporoblast wall appeared externally ridged (Fig. 15). Sporoblast and later spore wall either stayed in direct contact with plasmodium cytoplasm or were located within a small vacuole without a limiting membrane (Fig. 16). The isofilar polar tube became eventually neatly arranged in a single coil consisting of 6 to 9 turns around the walls of the posterior end of the spore.
In the spore, beneath the polar sac the laminar part of the polaroplast was well developed, unlike the vesicular part, which was rather small (Fig. 20). In the sporoplasm around the diplokaryon situated in the midspore length (Figs. $19 \& 20$ ), straight strands of polyribosomes were found (Fig, 17). The large posterior vacuole contained clumps of membraneous material. In mature spores, the endospore was approximately $96 \mathrm{~nm}$ and the exospore $15 \mathrm{~nm}$ thick (Fig. 19).

Figs. 1 \& 2. Plasmodium of Ortholinea polymorpha heavily infected with Nosema notabilis. Arrowheads point at pinocytotic invaginations; arrows point at pseudopodialike surface projections. * marks anomalous structures in the cytoplasm. Di: nuclei of the diplokaryon; $M$ : meront; mi: mitochondria; Nu: vegetative nucleus of the plasmodium $_{i}$ S: spore Si: immature spore. Scale bar $=2 \mu \mathrm{m}$ in both figures

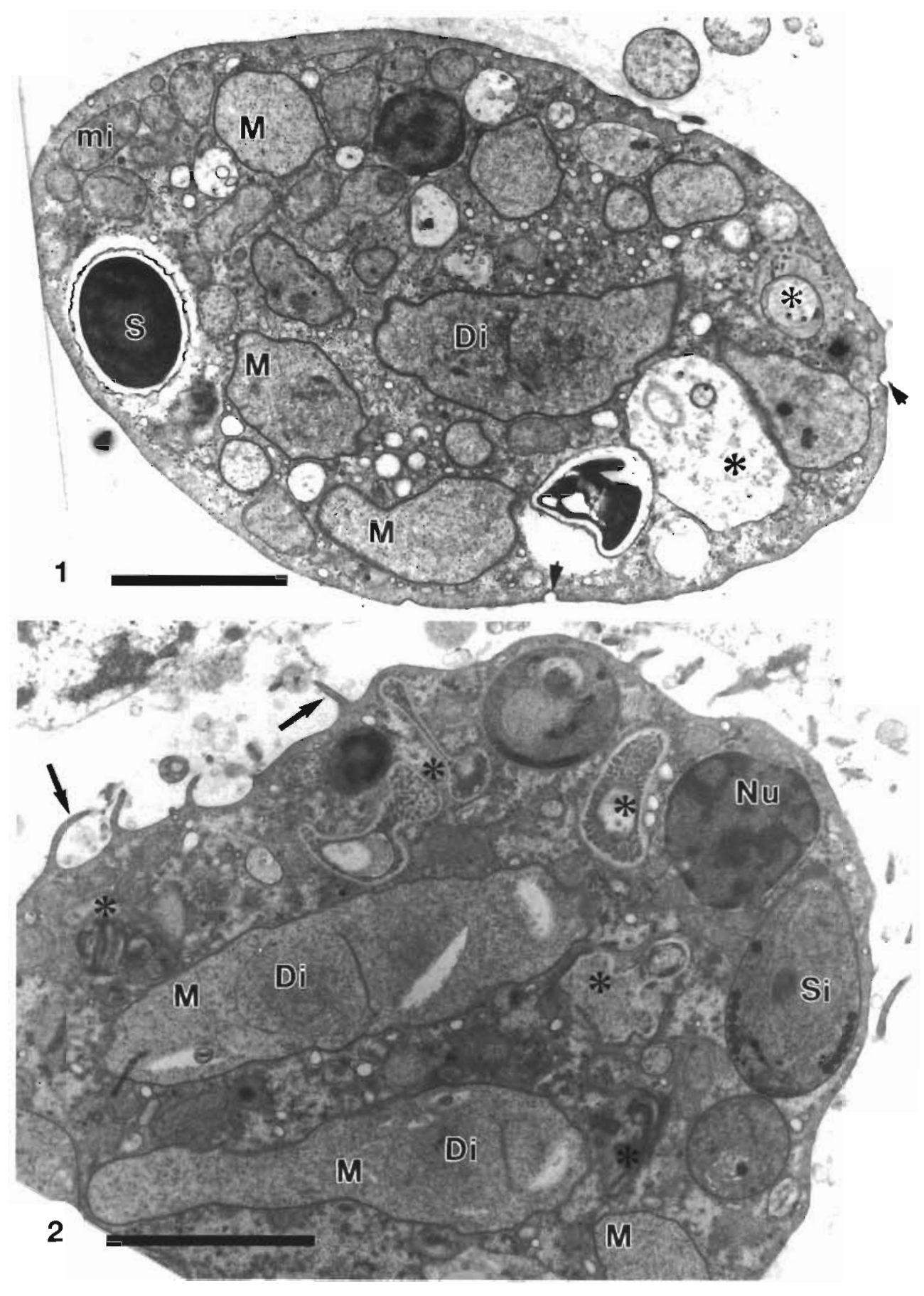



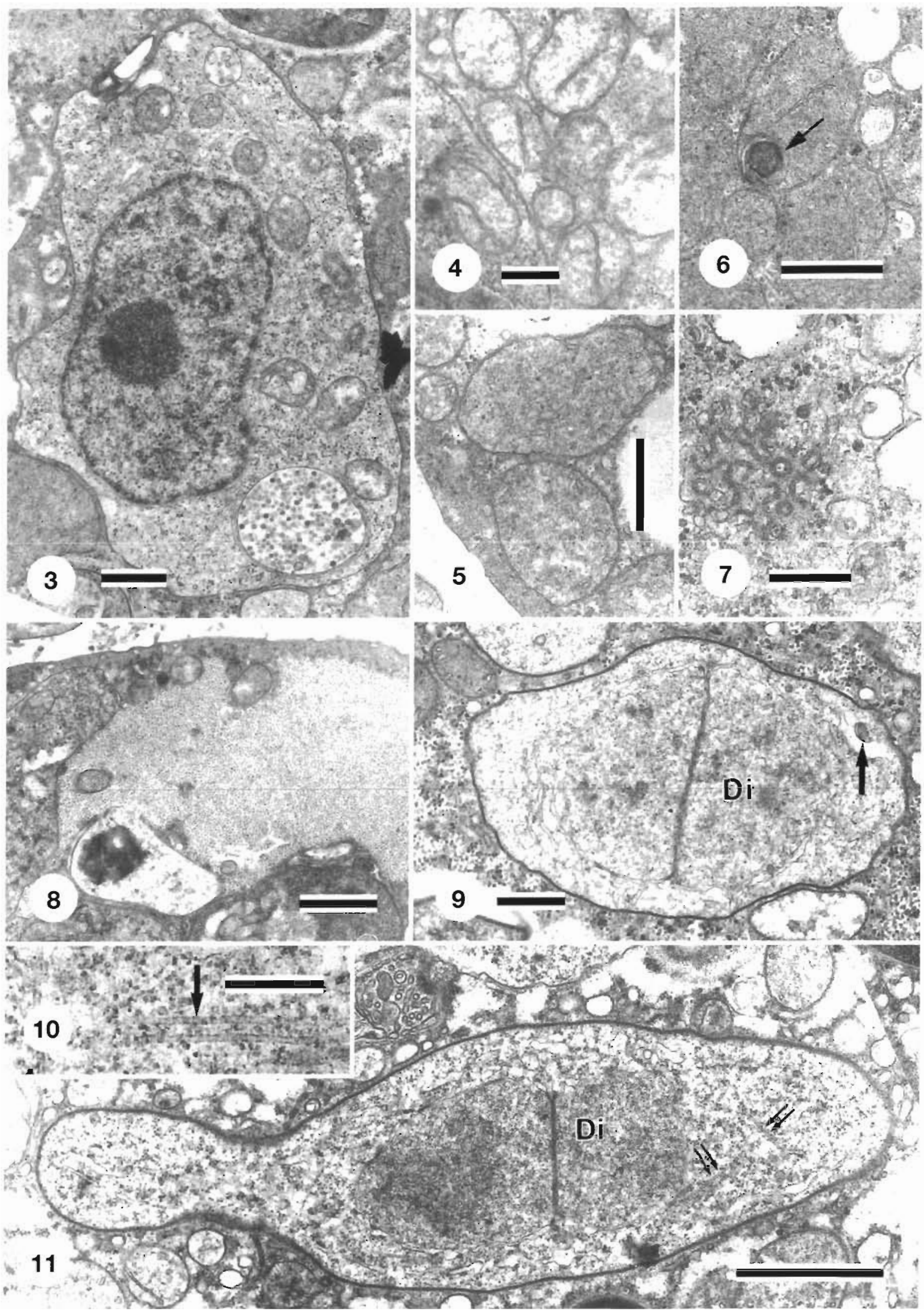

Figs 3 to 11 Ortholnea polymorpha infected with Nosema notabilis Fig 3 Generative cell showing the first sign of damage, a vacuole filled with dense globules. Scale bar $=05 \mu \mathrm{m}$. Fig 4 . Unaltered mitochondna from an unutected plasmodium Scale bar $=250 \mathrm{~nm}$. Figs. 5 \& 6 . Greatly hypertrophic mitochondria with indistunct cristae from infected plasmodıa, arrow points at a dense inclusion Scale bar $=05 \mu \mathrm{m}$ m both fıgures Fıg. 7. Convoluted profiles of endoplasmic retıculum. Scale bar $=250 \mathrm{~nm}$. Fig. 8 Island of granular substance in the cytoplasm next to a vacuole with dense matter Scale bar $=1 \mu \mathrm{m}$ Fig 9 Early meront with diplokaryon (Di), arrow points at a membranous whorl. Scale bar $=05 \mu \mathrm{m}$. Fig. 10. Microtubules (arrow) in meront cytoplasm. Scale bar $=250 \mathrm{~nm}$. Fig 11 A growing meront Arrows point at the cytoplasmic microtubules. Di diplokaryon Scale bar $=1 \mu \mathrm{m}$ 


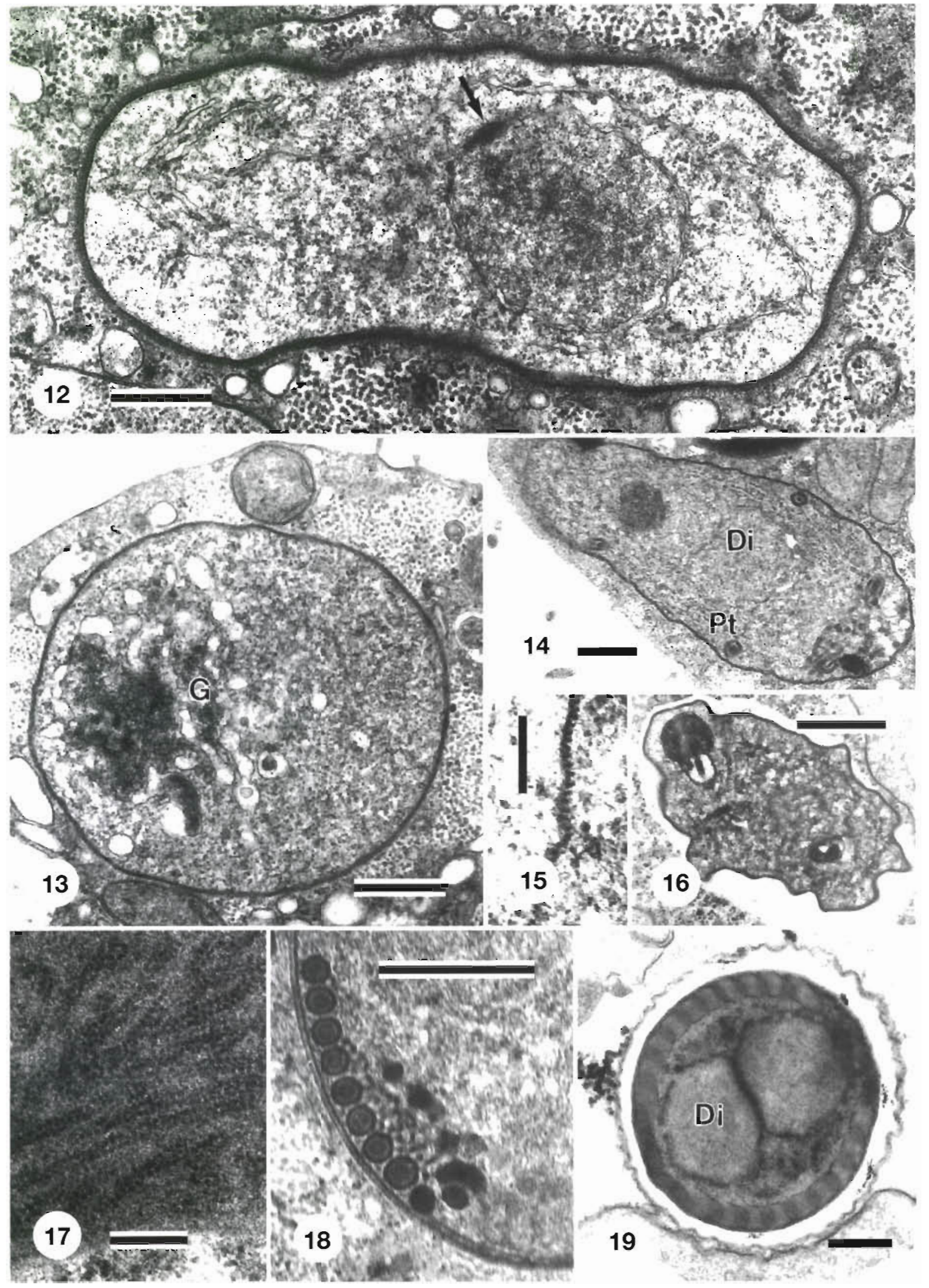

Figs. 12 to 19. Ortholinea polymorpha infected with Nosema notabuls. Fig. 12, A sporont with 1 nucleus only seen in the section. Arrow points at the spindle plaque. Scale bar $=0.5 \mu \mathrm{m}$. Fig. 13. Nascent Golg $\operatorname{system~(G)~in~the~sporont~Scale~bar~}=0.5 \mu \mathrm{m}$ Fig. 14. Late sporoblast/early spore. Pt: polar tube; Di diplokaryon. Scale bar $=05 \mu \mathrm{m}$. Fig. 15. Ridged outer surface of the sporoblast. Scale bar $=250 \mathrm{~nm}$. Fig. 16. Sporoblast with crumpled cell wall and prumordium of the polar sac Scale bar $=1 \mu \mathrm{m}$ Fig. 17. Strands of polyribosomes in a mature spore. Scale bar $=200 \mathrm{~nm}$. Fig. 18. Sectioned polar tube with remnants of the Golgl system at the back of an immature spore. Scale bar $=0.5 \mu \mathrm{m}$. Fig. 19. Transverse section of a spore. Di. diplokaryon Scale bar $=250 \mathrm{~nm}$ 
A considerably large proportion of the stages underwent an anomalous development; some plasmodia appeared full of them (Fig. 25, arrows). Some spores revealed minor anomalies, e.g. only affecting the polaroplast (Fig. 24). Some stages reminded one due to their shape and size of a maturing spore with a thick wall; they revealed an apical star of dense rods (Fig. 21) and a completely malformed content. The apical rods were a frequent phenomenon. However, the development of the sporoblasts seemed to go wrong most often, turning these into formations full of tortuous tubules (Fig. 23), membranaceous bodies and/or globules with vacuoles. Some of the tubules looked stellate in cross section (Fig. 22), with an inner doublewalled tube and outer ridges. The structures supposedly derived from aberrant development preserved an ovoid shape or were completely distorted (Fig. 25). Often they were encased with a membrane; sometimes they were lying free in the hosts' cytoplasm.

\section{DISCUSSION}

Infection with Nosema notabilis had serious pathological effects on its host plasmodium. Essentially, they are comparable to changes induced by $N$. ceratomyxae in plasmodia of a Ceratomyxa sp. (Diamant \& Paperna 1989). Identical features were observed: disappearance of surface pinocytotic vesicles, disturbance of sporogenesis, pyknosis of vegetative nuclei, degenerative signs in the cytoplasm, and, eventually, disintegration of plasmodia. As for mitochondria, the 2 authors did not observe an anomalous appearance, which in $N$. notabilis possibly reflected an essential pathogenic influence of the parasite. However, in mitochondria in the plasmodium cytoplasm they observed a structure which normally only occurs in the sporoblasts.

Cisternae of ER in the form of convoluted tubules (Fig. 7) have also been observed in apparently normal plasmodia of Ortholinea fluviatilis (Lom \& Dyková 1996); hence, they need not be a pathological sign.

Our observations revealed ultrastructural features (e.g. direct contact with host cell cytoplasm, details of meront division) confirming the assignment of the microsporidian to the genus Nosema. However, unlike Kudo (1944), we did not observe the descent of a single sporoblast from the sporont, contradicting the generally accepted diagnosis of the genus. Curiously, some questions concerning the development of Nosema have still not been satisfactorily answered (Sprague et al. 1992) and thus warrant further study.

The ultrastructure of developmental stages of Nosema notabilis displayed in general the same features as $N$. ceratomyxae (Diamant \& Paperna 1985), including membrane-less halos around some of the mature spores. Similarly, both species have in common a very high percentage of teratological sporogony yielding distorted structures only vaguely reminiscent of spores but actually consisting primarily of convoluted tubules, vesicles, vacuolated dense bodies and vacuoles. Diamant \& Paperna (1985) presumed that the deviation may be caused by failure of the sporoblast to receive the nucleus during the sporogonial division resulting in deficient spores. This is a conjecture difficult to confirm or disprove. It is interesting to note, however, that teratological development of spores has been observed in Enterocytozoon bieneusi (Ditrich et al. 1994) and in some cell cultures of Encephalitozoon hellem (D. Schwartz unpubl.). One can only speculate as to which factors in these host-parasite systems affect sporogony by inducing malformed stages.

In the 2 species Microsporidium acanthocephali and $M$. propingui, which are hyperparasitic in acanthocephalans, Loubes et al. (1988) noticed that the host cell membrane enveloping sporogonic and merogonic stages was associated with strange twisted fibres; they did not record any damage to host cell cytoplasm or malformed microsporidian stages.

The thick dense coat on sporonts deposited first in the ridges is obviously a common feature to be found in various microsporidia (e.g. Encephalitozoon cuniculi [Barker 1975, Hamilton et al. 1977]; Nosema tractabile [Larsson 1986]).

The tubular formations produced in association with degraded sporoblasts or spores may appear similar to tubules derived from exospores of sporogony stages of some microsporidia (e.g. in Agglomerata cladocera [Larsson et al. 1996]). However, they also are a feature found in various other forms in microsporidia-they are reminiscent of the tubules in the well-known paramural bodies or in the interior of extruded spores (Lom 1970). Perhaps they are derived from the pool of mem-

Figs. 20 to 25. Ortholinea polymorpha infected with Nosema notabilis. Fig. 20. An immature spore with the end of the polar tube protruding into the posterior vacuole. Scale bar $=0.5 \mu \mathrm{m}$. Fig. 21. A malformed spore with thin endo- and exospore (arrows), and an apical star of dense rods. Scale bar $=1 \mu \mathrm{m}$. Fig. 22. Sections of tubules such as seen in Figs. $23 \& 25$. Scale bar $=100 \mathrm{~nm}$. Fig. 23. Tubular formations resulting from teratogenic sporogony. Scale bar $=0.5 \mu \mathrm{m}$. Fig. 24 . A spore in formation, with malformed polaroplast. Scale bar $=1 \mu \mathrm{m}$. Fig. 25. Part of heavily infected plasmodium revealing meronts $(\mathrm{M})$ and products of anomalous sporogony (arrows); asterisks designate pinocytotic vesicles and arowhead points at surface projections. Scale bar $=2 \mu \mathrm{m}$ 


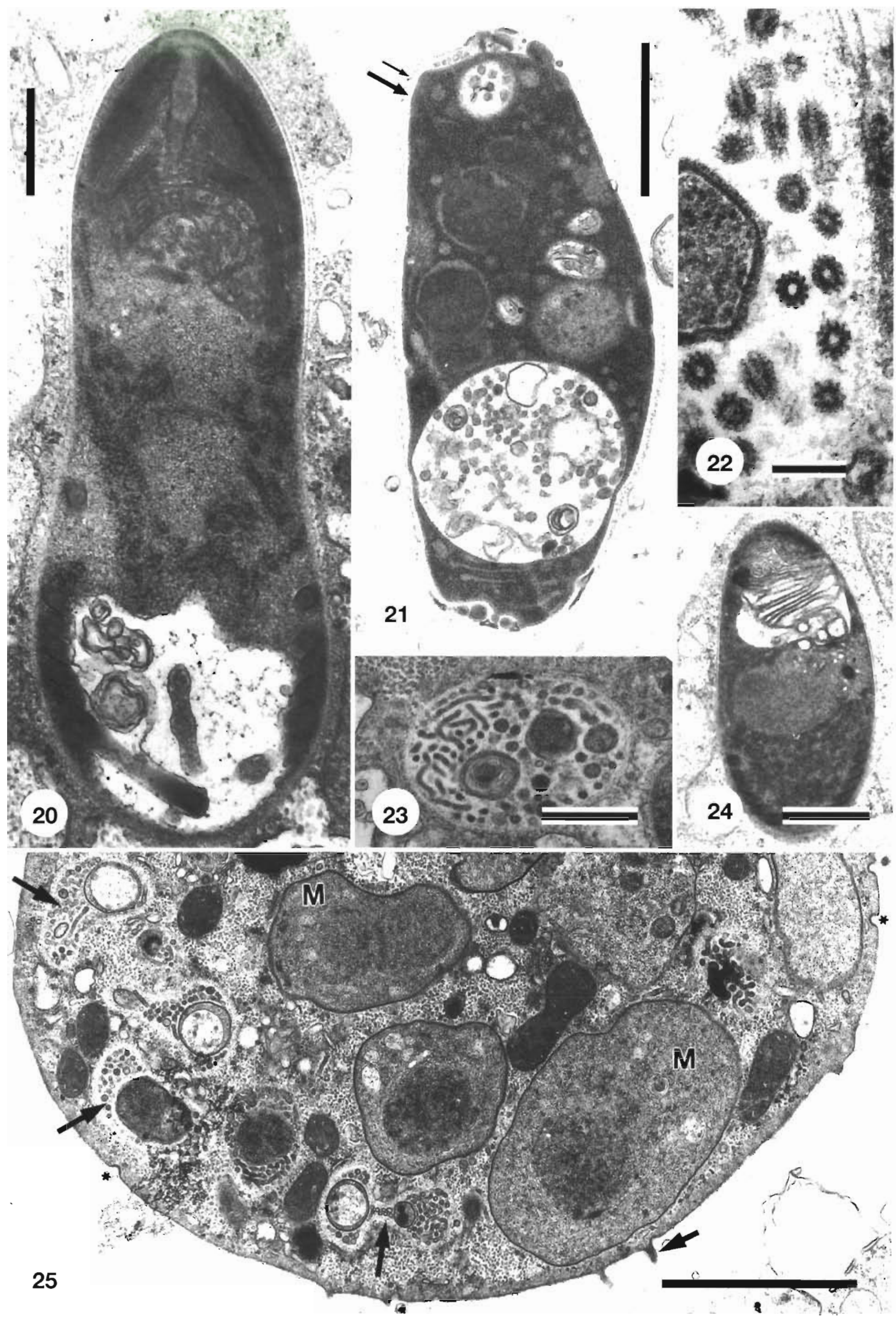


brane proteins in microsporidia (well expressed in polaroplasts), although this is just speculation based on superficial morphology. Their true origin is not known as previously stated by Diamant \& Paperna (1985).

As in all hyperparasitic microsporidia, it is difficult not to consider the route by which the Ortholinea polymorpha contracts the infection. Supposing the existence of an alternate host of the myxosporean (ElMatbouli et al. 1995) and the complicated route of the $O$. polymorpha presporogonic stages via the fish organism into the urinary bladder, it is hardly imaginable that the microsporidia could infect a supposed triaxtinomyxon stage and stay in it during its later transfomation into the myxosporean. In view of the evident absence of Nosema notabilis infection in fish tissues, one has to follow Kudo's (1944) conjecture that the infection takes place in the urinary bladder. The question remains, however, of how the sporoplasms from ingested spores reach the bladder and the piasmodium. This enigma seems even more troublesome than in microsporidia infecting digenean stages in mollusc intermediate hosts outside their digestive tract. Although several papers were devoted to this topic (see e.g. Canning et al. 1979, 1983) the actual penetration of the microsporidian into the digenean was not considered at all. In $N$. notabilis, various stages of development within the $O$. polymorpha plasmodia suggest that infection progresses gradually. In heavy infections, continuous spread of the parasite within the bladder has to take place, the mechanisms of which (spore hatching?) have also to be clarified.

Acknowledgements. This paper was supported by grant No. $524 / 98 / 0589$ awarded by the Grant Agency of the Czech Republic and by grant No. K2-022-601 awarded by the Grant Agency of the Academy of Sciences of the Czech Republic. The excellent technical help of Mrs M. Nešpůrková with electron microscopy sample preparation and of J. Bíca with printing photographs is greatly appreciated.

\section{LITERATURE CITED}

Barker RJ (1975) Ultrastructural observations on Encephalitozoon cuniculi from mouse peritoneal macrophages. Folia Parasitol 22:1-9

Canning EU, Barker RJ, Hammond JC, Nicholas JP (1983)

Editorial responsibility: Wolfgang Körting,

Hannover, Germany
Unikaryon slaptonleyi sp. nov. (Microspora: Unikaryonida) isolated from echinostome and strigeid larvae from Lymnea peregra: observations on its morphology, transmission and pathogenicity. Parasitology 87:175-184

Canning EU, Highby GC, Nicholas JP (1979) An experimental study of the effects of Nosema eurytremae (Microsporida: Nosematidae) on the liver fluke Fasciola hepatica. Parasitology 79:381-392

Diamant A, Paperna I (1985) 'The development and ultrastructure of Nosema ceratomyxae sp. nov, a microsporidian hyperparasite of the myxosporean Ceratomyxa sp. from Red Sea rabbitfish (Siganidae). Protistologica 21:249-258

Diamant A, Paperna I (1989) Cytopathology of Ceratomyxa sp. (Myxosporea) hyperparasitized with the microsporidan Nosema ceratomyxae. Dis Aquat Org 6:75-79

Ditrich O, Lom J, Dyková I, Vávra J (1994) First case of Enterocytozoon bieneusi in the Czech Republic: comments on the ultrastructure and teratoid sporogenesis of the parasite. J Eukaryot Microbiol 41:35S-36S

El-Matbouli M, Hoffmann RW, Mandok C (1995) Light and electron microscopic observations on the route of the triactinomyxon sporoplasm of Myxobolus cerebralis from eprdermis into rainbow trout cartilage. J Fish Biol 46: 919-935

Hamilton RC, Cox JC, Pye D (1977) Wall structure of the sporonts of Encephalitozoon cuniculi grown in human fibroblasts. J Gen Microbiol 98:305-307

Kudo RR (1939) Observations on Nosema notabilis n.sp., parasitic in a myxosporidian. Anat Rec (Suppl)75:153

Kudo RR (1944) Morphology and development of Nosema notabilis Kudo parasitic in Sphaerospora polymorpha Davis, a parasite of Opsanus tau and O. beta. Ill Biol Monogr 20:1-83

Larsson JIR (1986) Ultrastructure, function and classification of Microsporidia. Prog Protistol 1:325-390

Larsson JIR, Ebert I, Vávra J (1996) Uitrastructural study of Glugea cladocera Pfeiffer, 1895, and transfer to the genus Agglomerata (Microspora, Dubosquiidae). Eur J Protistol 32:412-422

Lom J (1970) On the structure of the extruded polar filament. Z Parasitenkd 38:200-213

Lom J, Dyková I (1996) Notes on the ultrastructure of two myxosporean (Myxozoa) species, Zschokkella pleomorpha and Ortholinea fluviatilis. Folia Parasitol 43:189-202

Lom J, Weiser J (1972) Surface pattern of some microsporidian spores as seen in the scanning electron microscope. Folia Parasitol 19:359-363

Loubes C, Maurand J, de Buron I (1988) Premieres observations sur deux microsporidies hyperparasites d'acanthocephales de poissons marins et lagunaires. Parasitol Res $74: 344-351$

Sprague V, Becnel JJ, Hazard El (1992) Taxonomy of phylum Microspora. Crit Rev Microbiol 18:285-395

Thélohan P (1895) Recherches sur les myxosporidies. Bull Sci Fr Belg 26:100-394

Submitted: July 15, 1998; Accepted: September 16, 1998

Proofs received from author(s): December 10, 1998 